\title{
Science, Technology and Innovation (STI) Policy for Sustainable Development
}

\author{
Most. Asikha Aktar * \\ Assistant Professor, Department of Economics \\ Comilla University, Cumilla, Bangladesh \\ Email: asikharita@gmail.com \\ Mukaramah Binti Harun \\ Associate Professor, School of Economics, Finance \& Banking \\ Universiti Utara Malaysia, Sintok, Kedah, Malaysia \\ Email: mukaramah@uum.edu.my
}

Md. Mahmudul Alam

Associate Professor, School of Economics, Finance \& Banking

Universiti Utara Malaysia, Sintok, Kedah, Malaysia

Email: rony000@gmail.com

* Corresponding Author

\section{Citation Reference:}

Aktar, M.A., Harun, M.B., Alam, M.M. (2020). Science, Technology and Innovation (STI) Policy for Sustainable Development. In: Leal Filho W., Azul A., Brandli L., Lange Salvia A., Wall T. (eds) Affordable and Clean Energy. Encyclopedia of the UN Sustainable Development Goals. Springer, Cham. ISBN: 978-3-319-71057-0. DOI: https://doi.org/10.1007/978-3-31971057-0_59-1

This is a pre-publication copy.

The published article is copyrighted by the publisher. 


\section{Science, Technology and Innovation (STI) Policy for Sustainable Development}

\section{Definition}

Universally, as a key and essential driver of accomplishing the Sustainable Development Goals (SDGs), Science, Technology and Innovation (STI) are recognized as a fundamental ingredients (Anand and Kedia 2015). There is a growing appreciation that in a multifarious ways, STI can drive inclusive growth and sustainable development. To construct an appropriate environment for STI to contribute its role to sustainable development, STI policy began taking an explicit form in the 1960s as a means for increasing the competitiveness of economies, while including also mission-oriented programs in defense, space, or transport, among others fields. Initially inspired by a linear, science-push, model of the innovation process, policies have become more complex over the years, recognizing the diversity of factors and actors that intervene in the process. The notion of "innovation systems", formulated in the late 1980s, has provided the conceptual basis of STI policies since then (UNCTAD 2019).

Lundvall and Borrás (2004) argued that science, technology and innovation policies individually target diverse features of the system and it is important to understand their key features before conceptualization. Such as, the aim of science policies is to ensure an adequate resources for science. While, the focus of technology policies is mainly on particular sectors and technologies which are measured tactical for the country (Chaminade and Padilla-Pérez 2014). Nelson (1994) finally define innovation policies as a more holistic type of policy, by which science and technologies come together in a special way. Lundvall et al. (2009) argued that they all target the innovation system and intrinsically they cannot be disentangled from each other, as they are both sides of the same coin. Fig. 1 depicted the relationship between them.

Therefore, STI policies are referred to as a set, which means that, although they have indeed expanded on a different nature and specific ecosystems, they can be considered in a continuum towards commercialization from an innovative knowledge (United Nations, 2015). Simultaneously, STI policies refers to the creation of new products and processes along with their expansion and application, can drive the economic frontier outward as well as assist to decoupling growth momentum from the depletion of natural resources (OECD 2010).

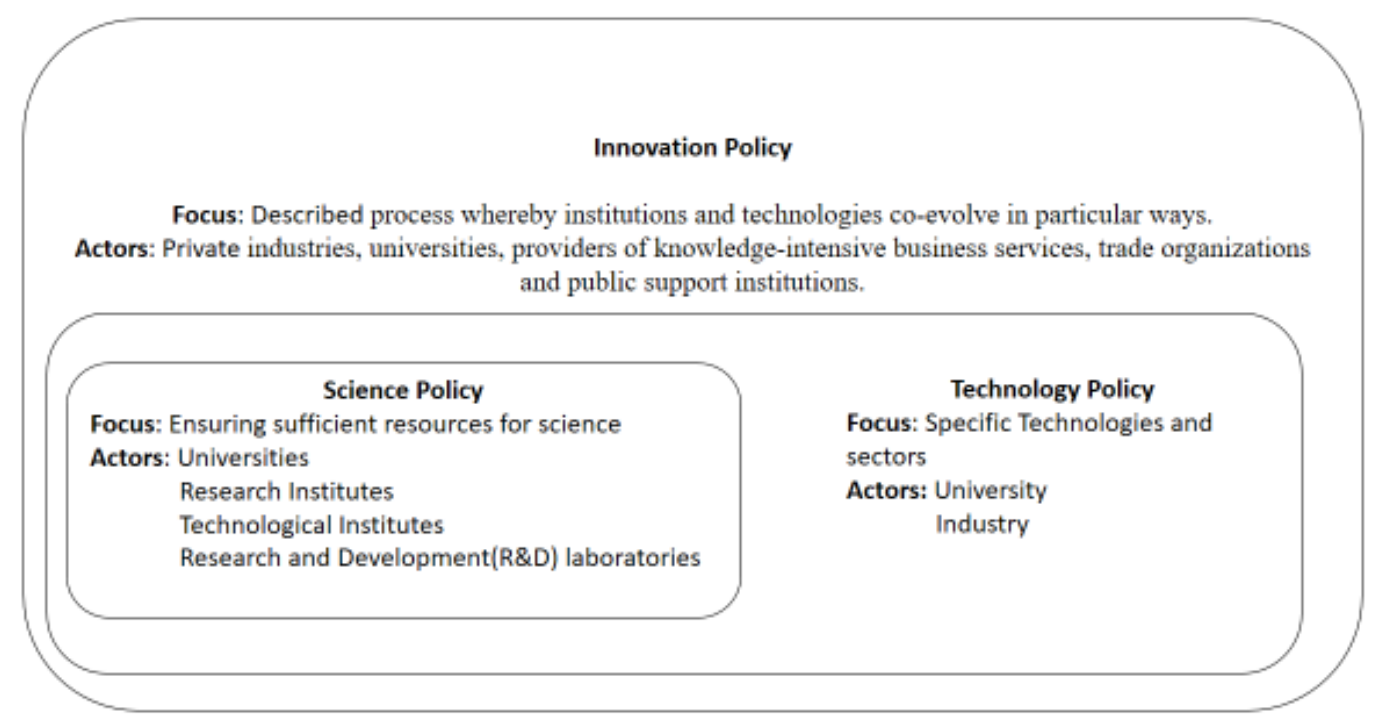

Figure 1: Relationship between science, technology and innovation policy Source: Author's Elaboration 


\section{Introduction}

The idea of the transition' toward 'green economy' or 'low-carbon economy' has emerged in the first era of the new millennium as an innovative policy statement (Steward 2012). The details of the necessity for an innovative and transformational response to the environmental sustainability issue has shifted to the mainstream from the political extremes. It combines policy landscape change with a new focus on innovative solutions for sustainability, commencing climate change as a 'serious issue' in the modern scientific world. Therefore, with the unprecedented threats from climate change and rising variability, governments around the world are embracing ambitious goals to reduce greenhouse gas (GHG) emissions. As well to avoid catastrophic effects on the planet and the people, there is a widespread recognition of the dominant policy circle in the urgent need of fundamentally restructuring the economy and society of the modern industrial world. The latest European policy paper states that our economy will have to undergo a radical shift in the behavior of the producer and consumer and, hence across generations (EU 2011b).

In this context of addressing climate change as a wide-ranging 'transformation' to a low carbon economy, attention has more recently been paid to the transformative innovation towards more inclusive and more environmentally sustainable patterns of development (UNCTAD 2019). Therefore, this would be a combination of both the societal and technological transformation, not just only installing new advanced technologies. It involves a new choice of policy toolsbut still it is only a part of the dialogue and hardly integrated and used in the policies plan. Therefore, it is looked-for appropriate frameworks of STI policy and governance in the forms of participating is required to be reinstated and established.

While, recognition also stems from the fact that the development of the STI policy framework is urgent and well-timed matter, as well as researchers and policy-makers in this area should not be wait to ripen the framework of STI policies. Which can withstand double social and environmental challenges in addition to immediate and cost-effective changes to the new sociotechnological systems. Therefore the policy need to be Cross-cutting as well as interactive in nature for building the fundamental block of sustainable development and also involved with a wider range development stakeholder through the channel of communication. Therefore, an outline is provided to reform and upgrade national STI policy within the framework of 2030 agenda for SDGs.

\section{Science, Technology and Innovation (STI) policies}

Contemporary economic development is generated through a set of socio-technological systems, which employs fossil fuels energy resources, and generate huge amount of GHG emissions; likely to foster climate change and in effects rising sea levels, melting ice-sheet, changes the patterns of monsoon and also tropical cyclones, droughts and floods going up (Schot and Steinmueller 2018). Therefore, climate change as a holistic threat to sustainable development goals has been approved globally (IPCC 2007). In this context, the European Union at the climate change discussion has introduced the conception of 'low carbon path' of growth with an unknown peaking point for carbon emissions.

This has become an important issue in many countries that a fair and well-organized domestic and international policies coordination leading the way in encouraging track on low carbon development. IPCC (2007) states that the increasing awareness is likely to further reduce GHG emission using current technologies from the subsequent period to 2020. Even though some of the technology are attractive economically by this time, still their diffusion remains low and disappointing to slowing down the GHG emissions in the short-run.

Moreover, for a decade now, the government around the world has recognized that they may need to bring into line the innovations which are required for sustainability (Walz et al.2017) 
would be 'transformative' in nature. Such the requirement of a transformative innovation policy to combat climate change and sustained socio-economic growth (including the "no one will be left behind") and integration, where economic, social and environmental dimensions are no longer a separate pillar but rather as involved in the creation of an integral content has turned into contests and opportunities for STI policy.

Through innovation such as the Horizon 2020, the European Union hopes to tackle most specific socio-economic challenges and create an inclusive economics, as well as participate in low carbon turnover (European Commission 2012). The Lund Declaration of 2015 clearly gives priority to the training of a new group of scholars who, through a superb research base will underpinned the collective socio-economic and environmental challenges. Also, recently signed treaty by the worldwide Paris climate change sets the target of reaching zero net carbon emissions in the $2^{\text {nd }}$ half of the century, and 17 Sustainable Development Goals (SDGs) has framed by the United Nations (2015) calls for greener production, sustainable patterns of consumption, increased social righteousness, better-quality wellbeing and innovative techniques to produce economic output.

Such context, STI policy that is originated from the assumption that innovation- both technical and social is a driver to create a better world (Schot and Steinmueller 2018). The notion is that new technology development will lead to developed labor efficiency and thereby increase the competitive status and sustainability of development. The expectation is that, policy regulation can manage the remaining externalities as well. Therefore, the innovation policy will emphasize the R\&D stimulus and subsequently the creation of a national innovation system. The idea is that this policy will enable the government to invest in green energy technology, reduce the amount of pollution, and clean up the atmosphere which will ultimately contributes to the transition of green growth

The key feature of the STI policy mentioned by Anand and Kedia (2015) is that it derives from existing analysis, does not follow the linear research pathways, goes through the development processes and planning of industrial production and ends up along with a successful starter of launching new innovative products and processes to the market. However, it is a cumulative and an interactive process consisting of a constant feedback loop at different stages. The second key feature is that it essentially results in an interactive process among many actors, including universities, companies, and research institutes. Recent feature surrounding STI policy refers transformative change to innovate technologies needed to be regarded as 'transformative innovation' with a reduced impact on the environment associated with social and economic change (Schiederig et al. 2012).

This brief outlines the role of the STI policy in recognizing the need for "transformative innovation" and implementing the SDGs to close trade-offs between economy, society and the environment. Figure 2 shows the processes where performance of innovation on the one hand and sustainable development on the other can affect each other over time mutually. Therefore, the transition toward a pathway to sustainable development can be accelerated by motivating national R\&D incentives for the development of low carbon economy, establishing incubation centers for low-carbon technology allied with the strong collaboration between industry, university and the government, facilitating diffusion of technology transfer organizations, among others an effort to transform informal sector to the low carbon economy as well. 


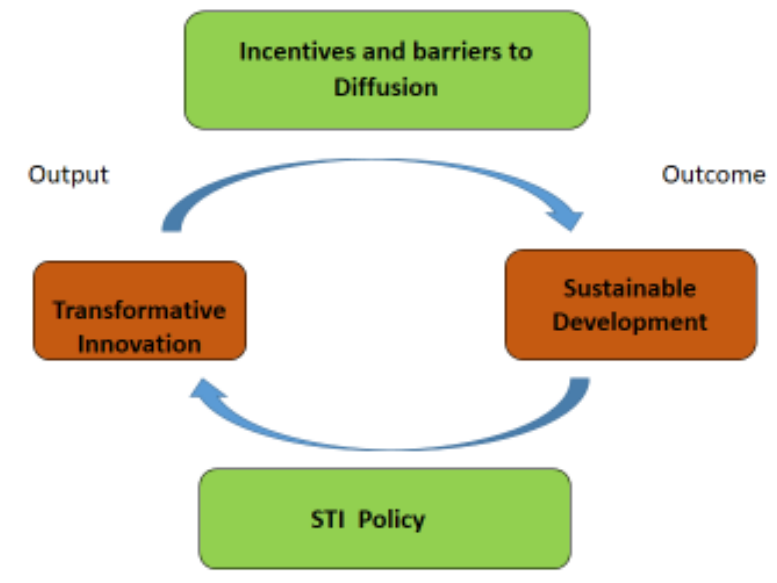

Figure 2: Interdependencies between transformative innovation and sustainable development Source: Anand and Kedia 2015

Therefore, the STI policy is designed by three continuous frames generated in the historical context (Schot and Steinmueller 2018). The $1^{\text {st }}$ framing is motivated by the innovation for development, sustaining the possibilities of science and technology for success, and fostering systems of socio-technology concentrating toward sustainable consumption and production. The $2^{\text {nd }}$ framing - national innovation systems which was established in the period of the 1980s addressing some of the significances of the experience of individual nation states in relation to contemporary economic growth such as the intensity of global competition, the possibility of being left behind, globalization, and the commitment of being caught.

Therefore, the $3^{\text {rd }}$ framing was created as a call for a transformative change ("2030 Agenda") of the world to a sustainable pathway by tackling the existing environmental and social challenges of attaining SDGs, although it has existed for many years in the discussion of policy debates; it was currently recognized by the OECD, published in the 2015 UN SDGs (Steward 2012; Weber and Rohracher 2012; Frenken 2017).

Part of the third framing approach involves the internalization of environmental costs into mainstream economic logics that can serve as a driver for sustainability innovation. Such framings arise a questioning of how to design STI policy at an initial level to address the issues of climate change with meeting environmental goals and, social needs and inclusive economic growth than earlier framings, and their related principles or objectives. Therefore, the research on sustainability transitions studies contend that transformation with the decarburization of the energy system as such play significant role in contemporary societies backbone systems (Grin et al. 2010; Markard et al. 2012; Steward 2012; OECD 2015).

Since, the production and consumption of energy accounts for about two-thirds or more than of the (68\% in 2014) global GHG emissions (World Economic Forum 2018). This has become a serious concern for a number of countries, in addition to adding more urgency to tackling sustainable energy issues, ensuring the energy security, affordability, and availability to all. Such a recognition of the need for transformative change in the energy system requires STI policy to embrace various forms of technological, social and institutional innovations, ranging from the incremental to the radical, and from low-tech to high-tech. Also includes many other forms of innovation, such as marketing innovation, inclusive innovation, and grass roots innovation. Table 1 introduces various types of innovation.

Table 1: STI policy to embrace various forms of Innovation in the energy system 


\begin{tabular}{|c|c|c|c|c|c|}
\hline $\begin{array}{l}\text { Technologic } \\
\text { al } \\
\text { innovation }\end{array}$ & $\begin{array}{l}\text { Social } \\
\text { innovatio } \\
n\end{array}$ & $\begin{array}{l}\text { Organizatio } \\
\text { nal } \\
\text { (institutiona } \\
\text { l) innovation }\end{array}$ & $\begin{array}{l}\text { Marketin } \\
\mathrm{g} \\
\text { innovatio } \\
\mathrm{n}\end{array}$ & $\begin{array}{l}\text { Inclusive } \\
\text { innovatio } \\
\text { n }\end{array}$ & $\begin{array}{l}\text { Grassroots } \\
\text { innovation }\end{array}$ \\
\hline $\begin{array}{l}\text { (i.e., } \\
\text { renewable } \\
\text { energy, } \\
\text { energy } \\
\text { efficient and } \\
\text { energy } \\
\text { savings } \\
\text { technologies) } \\
\text {. }\end{array}$ & $\begin{array}{l}\text { New } \\
\text { collaborati } \\
\text { ve } \\
\text { measures } \\
\text { on energy } \\
\text { by } \\
\text { considering } \\
\text { social and } \\
\text { environme } \\
\text { ntal } \\
\text { benefits }\end{array}$ & $\begin{array}{l}\text { Environmental } \\
\text { management } \\
\text { and auditing } \\
\text { systems (such } \\
\text { as ISO } 14001\end{array}$ & Labels & $\begin{array}{l}\text { innovation } \\
\text { designed } \\
\text { to address } \\
\text { the needs } \\
\text { of poorer, } \\
\text { marginaliz } \\
\text { ed groups }\end{array}$ & $\begin{array}{l}\text { Innovation that } \\
\text { involves grassroots } \\
\text { actors (NGOs, } \\
\text { communities) in the } \\
\text { process of applying } \\
\text { Knowledge to } \\
\text { sustainable energy } \\
\text { challenges }\end{array}$ \\
\hline
\end{tabular}

Source: Drawn and adapted from Miedzinski et al. (2017a, 2017b); UNCTAD (2017); Radjou and Prabhu (2015); Dutrénit and Sutz (2014).

\section{Towards Science, Technology and Innovation (STI) policy for Sustainable Development}

With the world Rio+20 conference which took place in June 2012, many expects that the SDGs to be a promising outcome. Introduced first by the government of Colombia, this concept is now recognized by the government in the south and north, and importantly reported in the document's "zero draft" conferences and recommended by the UN superior level of panel on prominent issues of world Sustainability (UN GSP). It is now being argued that the SDGs will cover the entire gap beyond the 2015 targets of the Millennium Development Goals (MDGs) and also be an inheritor to the MDGs in terms of action and thinking related to economy and environment. Yet, as underlined in the present meeting of the New York's Centre for International Cooperation, there is very little clarity on what the SDGs should be involved in, who should deploy it, and how it to be implemented in reality (Evans and Steven 2012).

Therefore, SDGs that cover a varied range of issues including economic (production and consumption, employment, resilience, energy, etc.) social (poverty, education, health, gender balance, migration, etc.) and environmental (climate change, water and ecosystems, etc.). The Centre for STEPS, the Resilience Centre of Stockholm, and the Institute of Tellus argues that the SDGs that put human society in a "safe operating space" needed urgently at this moment in time ; reflecting a policy framework that encompasses all aspects of SD and needs to be firmly embedded in the decision-making of businesses, governments, and people.

Since, crisis in climate is already taking place on a much wider scale around the world, and are set to further rise by $1.4^{0} \mathrm{C}$ to $5.8^{0} \mathrm{C}$ by the end of the 21 st century, for instance we approach critical thresholds (IPCC 2007). In this critical stage of global climate, risks and vulnerabilities are high but also are opportunities for socio-technical system changes and transformations. What is important is that global sustainability come to be the basis for individual and interrelated social, economic, and environmental systems in total.

It calls for what Freeman (1992) termed as transformative change: refers to 'socio-technical system change ${ }^{1}$, therefore argued that transformation of the systems of socio- technical is

${ }^{1}$ STI policy can contribute to the introduction of renewable energy. However, if renewable energy is simply an alternative to conventional energy and the nation is driven by conventional energy -dominated innovation system, low carbon and inclusive economy will still be far away. Although, the structures of the industry may be transformative, the ambitious SDGs will not be met. 
required in key sectors of the economy including energy (Grin et al. 2010; Markard et al. 2012; Steward 2012; OECD 2015). Where, energy as a part of the environment at the moment is deliberated as a major impacting factor of the vastly interrelated world economy.

Such a "radical transformation towards a sustainable society as a response to a number of persistent problems confronting contemporary modern societies" known as sustainable transition (Grin et al. 2010) also encouraged a motivation to a new way of life, developing diverse path to growth and the structure of financial inducement that steadily internalize the cost of environment. While, the aim of internalizing environmental costs is not a new notion. There has been a growing concern since the early 1970s about the impact on environment of sustainable economic progress which has raised awareness about the sustainability of environment. Later in 1972, the Rome Club launched a review on the theory of 'Limits to Growth', that is considered by Meadows et al. (1972) as one of the cornerstones in the sustainability research. Based on such a theory, a group of scholars developed a world inclusive model where a number of complex systems interacted simultaneously reflects the visions of the world that are locally appropriate and socially applicable. Among all other things, the model simulates the interplay between economic, energy and environment.

Therefore, evolving different scenarios based on various alternative policies all leading to the same results: if the existing trend persists, the world climate change could have a catastrophic effects on the planet and people. Environmental economists 'Herman Daly (1977) considered this issue in the 1970s and stared criticizing the externalization of the cost of environment in the development context. Therefore, he propagated the idea of a stable economy such as the economy would not expand further than a definite level in order to maintain the global resource sustainability (O'Neill 2012). Another breakthrough was reached in 1987, when the Brundlandt report was presented to the UN by the World Commission on Environment and Development. This report is proceeded by the conceptualization of sustainability which implies that 'development' and environment' are not separable.

It defined sustainable development as "meeting the needs of the present without comprising the ability of future generations to meet their own needs". This report established that the limits that sustainable development entails are not definite, but imposed mutually by the capability of the planet to control the impacts of human actions and by the state of technology and societal institution. While, the enrichment of both the technological innovation and social institution therefore open up the opportunities for the future development prospects (Matos et al.2019).For the twenty-first century it is perceived as a prerequisite for sustainable economic growth. However, it will not take place spontaneously. Therefore, given the lack of instantly needed satisfactory policy acts to sustainability, Freeman (1992) as a necessary preconditions for policy- making refers to an analytical framework based on science.

Therefore, the initial point is to accelerate the development and deployment of ' $a$ transformative innovation policy' ${ }^{2}$ for transforming the world toward sustainable energy,

Therefore, it is contend that to implement STI policies along with a new transformation system in which conventional energy is not as much of important in contrast to renewable energy such as solar, wind, Hydroelectric, Geothermal, Ocean, Hydrogen, and Biomass. This is what we call socio-technical systems transformation, which involves the co-production of social, Behavioural and technological change in a related way. Socio-technical system transformation (or transition) refers to radical change in all aspects of societal elements corresponding their relations with high tech solutions and innovation in old technologies (i.e., changing industrial structure, infrastructure, abilities, consumer preferences, law and rules, as well as cultural predilections).

\footnotetext{
${ }^{2}$ Refers to the policy that support and produce transformational changes at a system level. The initiatives of such policy includes developing new innovation processes, building new partnership models and governance, creation of new market, and also includes changes at a level in Behavior, organizational, institutional, and monitoring
} 
which has gained one of the first policy priority by governments across the world in terms of heightened awareness of stabilizing the concentrations of GHG emissions and achieving the target of $1.5-2^{0} \mathrm{C}$ globally (Kedia 2016). Although twenty years ago in the 'advanced' Global North, innovation as a process of market-driven was the narrative of the 'green economy ' (Jacobs 1992; Pearce et al. 1989); it has recently been driven by the UN Environment Programme (UNEP 2011); and widely accepted as the key to the transformation process toward sustainability among many governments, business entities and NGOs.

Moreover, it is high time to integrate the social and environmental issues into economic discussion. By taking into account that the crisis between economy and environment will be unresolved without transforming our production and consumption level as well as our interaction with our globe. There is now an urgent need of an influential policy circles to fundamentally reshape the energy consumption and generation patterns of the modern industrialized world in order to avoid the disastrous effects of climate change on the atmosphere.

The Stern review (2006) illustrated new academic affairs to present the extensive idea of 'managing the transformative change of energy'. Although focused was mostly technologybased, the Stern review cited economic rationale for the policy innovation moved away from the market led, prevailing generic, incremental, and fair technical resolution. Instead mentioned that climate change is a result of the failure of market, so a wider transformation of technology was required, and which 'could not be provided via the markets'.

Therefore, achieving the national goals of a sustainable energy economy requires technologybased early stage deployment support. The advent of the concept of transition at the policy level was in this situation, go along with the transformed interest in a more state-run sustainable oriented innovation policy. It recognizes the urgency of innovation to reduce emissions, will include both the consumers and producers through the change in daily use of energy such as 'energy efficiency' as well as low-carbon alternatives to renewables energy production.

Initially as a key driver of enabling and accelerating the global energy transformation towards sustainability, the third frame for STI policy demonstrated the importance of innovation which has been recognized both in developing and developed countries by the Paris climate negotiations, COP 2015 (EU 2015). Although, STI features determinedly as a cross-cutting one to attain a number of sectoral targets and goals assigned in agenda 2030. Meanwhile, the experience of recent years shows that in most world biggest economies (including India, China and EU) were undertaken STI policy therefore posits that the policy system will "serve as a basis of strategic knowledge" to deal with the threat of climate change and also thanks to its strength not only for increasing productivity, prosperity and economic development, but also for sustaining environment (United Nations 2015; Anand and Kedia 2015).

In the same vein, the Addis Ababa Action Agenda (AAAA), which is a fundamental part of agenda $2030^{3}$ 'Transforming our World' recognizes that "the establishment, development and dissemination of new technologies and innovations and associated know-how, including the transfer of technology in terms of mutual agreement are influential drivers for moving to the sustainable world. Agenda 2030 thus set up a timely and urgent stimulus driving research and

structure. Framing this new policy not only develops the conception of innovation, but also improves the direction of innovation, which is defined more often by the challenges of social need (Schot and Steinmueller 2016).

3. The Agenda 2030- which aims to bring about transformative changes, indicates that these transformation will not only be driven by technology. In order to cope with the unpredictable consequences of the past and create new avenues and opportunities for the future, radical transformation required in the structure of the current economic, social and environmental systems both in parallel and inter-related way. STI are fundamental gears for such structural transformation. 
innovation policy further in this direction, highlighted that simply through the expansion or adjusting existing systems the goal of sustainability cannot be achieved.

However, fostering STI alone will not be sufficient as implementation of the goals of sustainable energy development requires unprecedented cooperation in case of facilitating governance and policy environments, rising human capacity and competence for innovation, effective use of public financing and mobilization, and harnessing the positive impact of mitigation and executing a constant monitoring and evaluating the results achieved to ensure full obligation of decision makers. Therefore, the theoretical frameworks developing in the field of sustainability transition and transformative innovation policy requires the emergence of a broader sustainable-driven policy agenda as necessity for the integration of various perspectives.

It is part of a facilitating governance environment that STI policies are fully integrated into overarching sectoral plans and policies. Simultaneously, such policies can contribute to creating an enabling environment for transformation. As well as the policy allows efficiency improvement in both the senses of economy and environment, developing a sustainable ways of satisfying social requirements for energy, reducing historical gaps, coordinating relationships between people and natural world, placing shared good with the interventions of development, qualifying people to initiate their individual future as well as benefiting people directly (e.g. biotech for smallholders, clean cooking stoves).

Therefore, the policy also provides the basis for a new global partnership that will ultimately bring a new spirit of unity and collaboration. To make this happen, development partners can work more effectively with the developed countries research and innovation actors for structuring STI capacities in the developing countries through technology transfer that can help them leapfrog to cleaner development patterns like renewable energy. Also can increase publicprivate expenditure and investment in research and development by boosting the public-private partnerships and joint R\&D with developed countries.

In conclusion, the STI policy for sustainable development" (henceforth STI4SD) is one of the key transformational forces for changing the existing unsustainable pathways globally. As such they could become an important component of future policymaking for each country and the key to the discussion of global policy community in regarding how to attain the SDGs.

\section{Policy Design: Upgrade National STI policy within the Framework of SDGs}

To legitimize STI policy several rationales have explored by Weber and Rohracher (2012). One of the main challenges is whether the State is capable to invest extensively and in a sustainable way in clean technologies. The potential loss of power to the nation-states is not being considered, however, as the key challenges. The more rudimentary challenge is whether externalities such as climate change which is caused by growth can be managed through the deployment of clean technology and distributional measures, in spite of having a strong state as well. The key difficulty is that the current $R \& D$ and national innovation systems for STI policy settings are not fit for addressing the challenges of sustainability.

They argue four types of failure: directionality, demand-articulation, policy harmonization and reflexivity reinforcing that existing innovation policies should be accompanied by policies directed toward transformation. Therefore, the STI policy aligned with the 2030 Agenda must be designed as an integrated package of innovations focus on transformation; to internalize and accommodate all three dimensions of sustainable development; providing direct support to innovators and improving the enabling environment for innovation activities that contributes to achieve sustainable development.

Therefore, policymakers need to learn how to design and implement policy plans and strategies, as well as specific instruments. Weber and Rohracher (2012) proposes that for designing STI 
policies more effectively to transformative change it could be a good starting point to analyze the characteristics of failures.

(i) Failure of Directionality

In general, STI policy is designed to address economic policy objectives by ensuring efficient functioning of the innovation system, keeping both market and system failures in mind. This rationale means the policy remains 'neutral' regarding the nature and direction of economic growth and does not give any explicit attention to environmentally and socially sustainable innovations.

This lack of explicit indication of an overall strategic direction, and the negative costs to society associated with the resultant forms of innovation, is referred to as directionality failure (Weber and Rohracher 2012). Addressing directionality failure means inadequate focus on the relationships between direction and SDGs or further challenges.

(ii) Failure of Policy harmonization

Denotes the lack of capability to harmonize policies horizontally from different perspectives. However, since transformational change means transforming various systems and ultimately changing social and economic structure, therefore, harmonization with other cross-cutting policies, as such economic policy, tax policy, and social policy, is important.

(iii) Failure of demand-articulation

Managing demand should be perceived as an innovative procedure of a policy action and also a novel procedure of a transformative governance policy (Turnheim et al. 2018). Although it is hard to confirm more often that such national spaces go beyond the conventional technical-based demonstrations and initial level of developments. As such demand experimentations, emphasis on delivery of a new shared belief and ideas, forming new network and reshaping the structure of market (called niches) that ultimately challenge the conventional markets and organizational key practices.

(iv) Failure of reflexivity

Addressing the failure of reflexivity is essential. According to Weber and Rohracher (2012) it is about the ability to anticipate, observe, and engage actors altogether in the transformative change of the self-governance process. Reflective learning processes assumes that actors analytically evaluate their individual choices and experimentation through another course of action. This is the case to address the reflexivity failure as well: the ability to see at a distance (it can be future imagination; or a set of challenges including environmental and social) from one's deeply fixed practices that stimulate collective behaviors and socio-technological change towards optimization rather than transformative change.

Therefore designing and planning STI policy along with the three dimensions: direction, diversification, and dissemination has been identified referring to the urgency of transformative innovation policy for attaining SDGs as well as to protect the planet for each generations (Leach et al. 2012).

(i) Direction

In order to be within a safe operating space and to achieve the goals of the sustainable development, STI policy changes should be concerned with a specific direction. This means focus should be clearly on specific goals and principles pouring policy and innovation, without being exposed, unobtrusive or driven by common obstacles to development or progress, but attention to direction refers most enthusiastically directing the policy to the sustainable pathways that is needed.

(ii) Diversification 
It is moreover essential. Fostering more diverse techniques and forms of innovation including social and technical lets us to respond to the ambiguity of avoiding the threats allied with "placing all the eggs in one carrier." Similarly, promoting diversification of energy resources provides more affluent resource base to nurture a further innovation to more robust and sustainable path. Here, the demands for proactive and target-oriented STI policies has emerged by the transition of sustainability to stimulate the expansion and placement of 'green' technologies.

(iii) Distribution

In line with the ambition to 'leave no-one behind', policymakers should consider the role and distributional implications of innovations and transformations for different communities, considering who are the gainer and who are the looser from such specific policies and innovations aiming to directed within it. Therefore, considering the trade-offs between national and local interests, setting SDGs and steering policy and innovation toward any goals requires keeping distributional issues at center stage - not just in achieving "trickle down," but in shaping fundamental directions of change and engaging instead of excluding people in ecosystem stewardship.

In addition, it would be better to design STI policies more forcefully according to the capabilities of actors and to the economic and societal structure of the respective country as regards to the beginning of a new mobility system. For example, the contribution of existing STI policy framings that developed since World War II still insignificant to manage the considerable negative magnitudes of modern economic growth on the socio-technical system, as little supervision offered by the policy where they have contributed and where they are a part of it.

Therefore, for implementing '2030 agenda' needs a very precise innovation process, that goes further than a business as usual scenario and present path-dependent systems. This approach of viewing the SDGs is consistent with target oriented STI policies in which targets are designed in an unrestricted way that induces investigation and diversification as well as development of innovation from a complexity-theoretic perspective (Frenken 2017). Other than for engaging and networking between the actors of public, private and third sector to design and implement policy instruments, and entire policy mixes new forms of innovation are required (Kuhlmann and Rip 2014; Foray et al. 2012).

\section{Possible Acts for Strengthening STI Policy}

It is important to create a viable environment for the development of STI policies to be a driving force of sustainable development. This implies that countries and regions need to ripen, implement and observe their domestic and local STI policies and programs as a wider part of development agenda that will enhance the creation, diffusion and application of knowledge, as well as the development and allocation of technological innovation that will eventually spur large scale production capabilities at a grassroots level.

Therefore, special attention is required by a nationwide governance systems to encourage widespread involvement in decision making regarding STI policies to attain any goals of sustainable development. More precisely, if we want a globe that will come to an end with the development and improvement of living conditions for all of its people, policies related to economic, social and environmental sustainability accompanied by the knowledge creation and technological innovations have to put in place all over the world. A number of notable acts can be followed to support the institutes and organization effusively for conducting the STI policies sustainability. As such-

- Engaging local stakeholders in the designing and implementing policy framework through building the network of excellence 
- Developing operationalizing mechanisms : finance and funds, organizational research agendas related to development agendas, ensure the knowledge cycle in society

- Encouraging coordination between the actors who are engaged in developing policy framework

- Promoting integration with other ministries including human resource development, environment among others

\section{Conclusion}

During the era when the scientific community recognizes the climate change (IPCC 2014), there is a growing awareness worldwide that there is a need to shift away from the low-carboneconomy. However, it calls for a "deeper transition" that seeks for a series of fundamental transformation with a broad and long-term social technological systems (Schot 2016; Schot and Kanger 2016. Weber and Rohracher 2012). It is critical to underline innovation as a key to develop the low carbon oriented technology which is needed for the transformation to a low carbon economy, and make it reasonable and available.

Currently, the linkage between the innovation policy and the transition of sustainability has stated more clearly in terms of "transformative innovation policy". Emphasizing that innovation policy for the transition of sustainability should be addressed along with policy mixes, instead of individual policy instruments (Flanagan et al. 2011; Rogge and Reichardt 2016; Veugelers 2012). While to harmonize and consolidate all of the innovation activities and programs, an overarching STI policy is crucial. It is indeed a strategic tool integrating various policy strategies and instruments into one strategic document and setting forth an implementation process.

As already indicated, STI policy is fundamental to take the economy, society and the environment onto a sustainable path. Enculturation of STI policy to address the challenges of sustainability identifying the overall sustainable development goals of a country. This goals can be achieved through adoption of a holistic STI policy approach keeping in mind that the process of deliberation of STI policies for sustainable development should be evidence based. Therefore, collaboration and participation between open stakeholder from different sectors such as government, academic, industry, and civil society is vital in structuring and harmonizing STI policies and measures to promote low carbon economy, encourage business innovation, and meet over-riding priorities.

\section{Synonyms}

Ingredients; tactical; integrate; interactive; transformative

\section{Cross References}

Innovations for Green Sustainable Development (Walz et al. 2017)

Technological innovation for sustainable development (Matos et al. 2019)

\section{References}

Anand M, Kedia S (2015) Innovation Policy and Sustainable Development. Brief for GSDR. The Energy and Resources Institute (TERI), New Delhi. Available at: https://sustainabledevelopment.un.org/content/documents/6559119Anand_Innovation\%20Policy\%20and\%20Sustainable\%20Development.pdf.

Chaminade C, Padilla Pé, rez R (2014) The challenge of alignment and barriers for the design and implementation of science, technology and innovation policies for innovation systems in developing countries. Lund University, CIRCLE Center for Innovation, 
Research and Competences in the Learning Economy. Available at: https://ideas.repec.org/p/hhs/lucirc/2014_026.html [accessed 17 February 2017].

Dutrénit G, Sutz J (Eds) (2014) National Innovation Systems, Social Inclusion and Development: the Latin American Experience. Edward Elgar publishing, Cheltenham UK.

European Commission (2012). KI-31-12-921-EN-C.

European Union (2011b) 571 Roadmap to a resource efficient Europe. COM (2011). Brussels: EU.

Evans A, Steven D (2012) Sustainable development goals - a useful outcome from Rio+20? Briefing, New York Centre on International Co-operation, New York, USA.

Flanagan K, Uyarra E, Laranja M (2011) The 'policy mix'for innovation: rethinking innovation policy in a multi-level, multi-actor context. Research Policy, 40(5), 702-713.

Freeman C (1992) The Economics of Hope. Pinter Publishers. London and New York.

Frenken K (2017)“A Complexity-Theoretic Perspective on Innovation Policy”, in Complexity, Governance \& Networks (2017) - Special Issue: Complexity, Innovation and Government Offices of Sweden (2017a), "Sweden and the Agenda 2030 - Report to the UN High Level Political Forum 2017 on Sustainable Development", July 2017. Stockholm.

Foray D, Mowery DC, Nelson RR (2012) Public R\&D and social challenges: what lessons from mission R\& D programs. Res. Policy 41 (10), 1697-1702.

Grin J, Rotmans J, Schot J (2010). Transitions to Sustainable Development: New Directions in the Study of Long Term Transformative Change. Routledge, New York NY.

IPCC (2007) Fourth Assessment Report: Climate Change 2007 (AR4) Working Group III Report. Mitigation of Climate Change. Geneva: IPCC Secretariat, c/o World Meteorological Organization.

Jacobs M (1992) Environment, Sustainable Development and the Politics of the Future. Pluto Press.

Kedia S (2016) Approaches to low carbon development in China and India. Advances in Climate Change Research, 7(4), 213-221.

Kuhlmann S, Rip A (2014) The challenge of addressing Grand Challenges: A think piece on how innovation can be driven towards the "Grand Challenges" as defined under the prospective European Union Framework Programme Horizon 2020. European Research and Innovation Area Board (ERIAB).

Leach M, Rockström J, Raskin P, Scoones IC, Stirling AC, Smith A ... Folke C (2012) Transforming innovation for sustainability. Ecology and Society, 17(2), 11.

Lundvall BA, Borrás S (2004) "Science, technology and innovation policy", in Fagerberg J, Mowery DC, Nelson RR, editors, The Oxford Handbook of Innovation, Oxford: Oxford University Press, pp. 599-631.

Lundvall BA, Joseph K, Chaminade C, Vang J (eds.) (2009) Handbook on Innovation Systems and Developing Countries: Building Domestic Capabilities in a Global Context. Cheltenham, UK: Edward Elgar.

Markard J, Raven R, Truffer B (2012) Sustainability transitions: an emerging field of research and its prospects. Res. Policy 41 (6), 955-967.

Meadows DH, Meadows DL, Randers J, Behrens WW (1972) The limits to growth: a report for the culb of rome's project on the predicament of mankind. Universe Books, New York NY.

Miedzinski M, McDowal W, Turkeli S, Kemp R (2017a) An expert-based participatory evaluation of public policies for sustainability transitions. Conference paper presented EU-SPRI Conference, Vienna, 7-9 June 2017. 
Miedzinski M, McDowal W, Bleischwitz R (2017b). Eco-innovation and resource nexus challenges: Ambitions and evidence, in R. Bleischwitz, H. Hoff, C. Spataru, E. van der Voet, S.D. VanDeveer (2017). Routledge Handbook of the Resource Nexus, Routlege, New York.

Matos LM, Anholon R, Filho WL (2019) Technological Innovation for Sustainability. Encyclopedia of Sustainability in Higher Education, 1904-1911.

Nelson RR (1994) The co-evolution of technology, industrial structure, and supporting institutions. Industrial and corporate change, 3(1), 47-63.

O'Neill DW (2012) Measuring progress in the de-growth transition to a steady state economy. Ecological economics, 84, 221-231.

OECD (2010) "The OECD Innovation Strategy: Getting a Head Start on Tomorrow". OECD Publishing, Paris.

OECD (2015) System Innovation: Synthesis Report. Paris.

Pearce DW, Markandya A, Barbier EB (1989) Blueprint for a Green Economy. Earthscan, London, Great Britain.

Radjou N, Prabhu J (2015) Frugal innovation: How to do more with less. New York: Public Affairs.

Rogge KS, Reichardt K (2016) "Policy mixes for sustainability transitions: An extended concept and framework for analysis", in Research Policy Volume 45, Issue 8, October, pp 1620-1635.

Schiederig T, Tietze F, Herstatt C (2012) Green innovation in technology and innovation management-an exploratory literature review. R\&D Management, 42(2), 180-192.

Schot J (2016) "Confronting the second deep Transition through the historical imagination", in Technology and Culture 57(2), pp 445-456.

Schot J, Kanger L (2016) "Deep transitions: emergence, acceleration, stabilization and Directionality". SPRU working paper series.

Schot J, Steinmueller E (2016) "Framing Innovation Policy for Transformative Change: Innovation Policy 3.0". Science Policy Research Unit (SPRU), University of Sussex. Retrieved from: http://www.johanschot.com/wordpress/wpcontent/uploads/2016/09/Framing-Innovation-Policy-for-Transformative-ChangeInnovation-Policy-3.0-2016.pdf.

Schot J, Steinmueller WE (2018). Three frames for innovation policy: R\&D, systems of innovation and transformative change. Research Policy, 47(9), pp.1554-1567.

Stern N (2006) Stern review report on the economics of climate change. London: HM Treasury, Cabinet Office.

Steward F (2012) Transformative innovation policy to meet the challenge of climate change: socio-technical networks aligned with consumption and end-use as new transition arenas for a low-carbon society or green economy. Technol. Anal. Strateg. Manag. 24 (4), 33313343.

Turnheim B, Kivimaa P, Berkhout F (Eds.) (2018) Innovating Climate Governance: Moving Beyond Experiments. Cambridge University Press, Cambridge.

United Nations (2015) Transforming Our World: The 2030 Agenda for Sustainable Development. Available at: https:// sustainabledevelopment.un.org/post2015/transformingourworld.

UNCTAD (2019) A Framework for Science, Technology and Innovation Policy Reviews: Harnessing innovation for sustainable development. UN publications, Geneva. Available at: https://unctad.org/en/PublicationsLibrary/dtlstict2019d4_en.pdf.

UNCTAD (2017) New Innovation Approaches to Support the Implementation of the Sustainable Development Goals. UN publications, New York, Geneva. Available at: https://unctad.org/en/PublicationsLibrary/dtlstict2017d4_en.pdf. 
Veugelers R (2012) "Which policy instruments to induce clean innovating?" in Research Policy, Volume 41, Issue 10, pp 1770-1778.

Walz R, Pfaff M, Marscheider-Weidemann F, Glöser-Chahoud S (2017) Innovations for reaching the green sustainable development goals-where will they come from? International Economics and Economic Policy, 14(3), 449-480.

Weber KM, Rohracher H (2012) Legitimizing research, technology and innovation policies for transformative change: Combining insights from innovation systems and multi-level perspective in a comprehensive 'failures' framework. Research Policy, 41(6), 10371047.

World Economic Forum (2018) Accelerating Sustainable Energy Innovation. White Paper.http://www3.weforum.org/docs/Accelerating_sustainable_energy_innovation_20 18.pdf [accessed on 22 may 2018]. 